\title{
Isolation of chlamydiae in untreated and Cytochalasin B treated McCoy cells
}

\author{
J. J. O'NEILL, BARBARA M. MCLEAN, AND M. H. HAMBLING \\ From the Public Health Laboratory, Bridle Path, York Road, Leeds LS15 7TR, UK
}

SUMMARY A comparison was made between untreated McCoy cells and McCoy cells treated with Cytochalasin B for the isolation of chlamydiae of subgroup A. Chlamydiae were isolated in both cell systems from 125 specimens, whereas six agents were isolated only in untreated cultures and seven agents were isolated only in Cytochalasin B treated cultures.

Although several different tissue culture techniques have been described for the isolation of chlamydiae, no single method appears greatly superior to all others. Gordon et al. (1972) reported that irradiated McCoy cells were more susceptible to Chlamydia trachomatis than non-irradiated cells. Later, Sompolinsky and Richmond (1974) showed that McCoy cells treated with Cytochalasin B were as efficient as irradiated cells for the isolation of chlamydiae. Further work by Richmond (1976) related the growth of Chlamydia trachomatis in untreated McCoy cells to the host-cell density, and Hobson et al. (1974), using untreated McCoy cells, successfully cultured Chlamydia trachomatis from clinical specimens. This report describes the isolation of Chlamydia trachomatis from clinical specimens inoculated into parallel cultures of untreated McCoy cells and cells treated with Cytochalasin B.

\section{Material and methods}

A total of 717 cervical swabs from women attending a clinic for sexually transmitted diseases at Leeds General Infirmary were collected for investigation for chlamydiae of subgroup A. The clinical features of these patients and an analysis of the results have previously been reported (Nayyar et al., 1976). The tips of the cervical swabs were broken off into $2.5 \mathrm{ml}$ of transport medium and sent to the laboratory in a vacuum flask containing water ice. In the laboratory the specimen was agitated on a Whirlimix (Griffin \& George Ltd) for one minute, and then 0.4-ml aliquots were inoculated into both cell culture systems. All specimens were inoculated into parallel cultures of McCoy cells (replicating cultures) and McCoy cells Received for publication 27 July 1977 treated with Cytochalasin B (non-replicating cultures).

PREPARATION OF MCCOY CULTURES AND CYTOCHALASIN B TREATED CELL CULTURES Coverslip (16 mm) monolayer cultures of McCoy cells in universal containers (1-oz screw-capped containers) were prepared by the method of Hobson et al. (1974). Each container was seeded with $2 \mathrm{ml}$ of McCoy cell suspension containing $1.2 \times 10^{5}$ cells $/ \mathrm{ml}$. Two series of coverslip monolayers were made; one series contained untreated cells, and in the other series $1 \mathrm{mg} / \mathrm{l}$ of Cytochalasin B (Imperial Chemical Industries Ltd) was incorporated in the growth medium, which was that described by Hobson et al. (1974). Before inoculation the growth medium in both series was replaced by maintenance medium consisting of Medium 199 (Wellcome), $100 \mathrm{ml}$; fetal calf serum, $5 \mathrm{ml} ; 4.4 \%$ sodium bicarbonate, $4 \mathrm{ml} ; 50 \%$ glucose solution, $1 \mathrm{ml} ; 10000 \mu \mathrm{g} / \mathrm{ml}$ streptomycin, 1 $\mathrm{ml} ; 10000 \mu \mathrm{g} / \mathrm{ml}$ vancomycin, $1 \mathrm{ml}$; and $200 \mu \mathrm{g} / \mathrm{ml}$ amphotericin (Fungizone), $1 \mathrm{ml}$. After inoculation all cultures were centrifuged at $3000 \mathrm{~g}$ for one hour at $33^{\circ} \mathrm{C}$ to $35^{\circ} \mathrm{C}$. The caps of the containers were loosened and the cultures were incubated at $37^{\circ} \mathrm{C}$ for 48 hours in an atmosphere of air and $5 \%$ carbon dioxide. After incubation coverslips were treated with Giemsa stain, mounted with DePeX, and examined microscopically by both dark-ground and conventional illumination for the characteristic chlamydial inclusions, the presence of which was recorded. Throughout the investigation all the cultures were examined by the same observer; if the culture was positive in one system only then both the positive and the negative cultures were examined by independent observers to verify the findings. 


\section{Results}

The results (see Table) show that chlamydiae were isolated from $138(19.2 \%)$ of the 717 specimens examined. Both cell systems produced 125 isolations whereas six agents were isolated only in replicating cell cultures, and seven agents were isolated only in non-replicating cultures.

Table Isolations of chlamydiae in untreated and Cytochalasin B treated McCoy cultures

\begin{tabular}{lr}
\hline Cervical swabs & No. \\
\hline Total & 717 \\
Positive for chlamydiae & 138 \\
Positive in both culture systems & 125 \\
Positive only in Cytochalasin B treated cultures & 7 \\
Positive only in untreated cultures & 6 \\
\hline
\end{tabular}

\section{Discussion}

It appears that under the conditions of this study there is no real difference in the sensitivity of the two systems for the isolation of chlamydiae of subgroup A. It was noted that when isolation was achieved in only one of the systems the positive coverslip culture contained very few inclusions (less than five) and a heavily infected coverslip was never found in parallel with a negative culture. The inclusions seen in the non-replicating cells were larger and more easily detected than those in the replicating cells when examined by conventional light microscopy, but this difference was not so noticeable when dark-ground illumination was used. Overgrowth of cells in the replicating cultures caused no difficulty in the interpretation of results if cultures were seeded with the cell suspension described.

Treatment with Cytochalasin B is a convenient method for producing non-replicating cell popula- 음 tions (Sompolinsky and Richmond, 1974), but, $\overrightarrow{\vec{F}}$ because of the possible toxic effects on those handling $\stackrel{+}{+}$ this material, alternative satisfactory methods for the isolation of chlamydiae may be preferred. Although the inclusions in untreated cells are usually smaller $\frac{\omega}{\vec{D}}$ than those in Cytochalasin B treated cells this has $\stackrel{D}{D}$ caused no difficulty during microscopic examination by dark-ground illumination, and in this laboratory $\vec{A}$ it is not considerd necessary to use Cytochalasin $B$ treated cells for the isolation of chlamydiae.

We are grateful to Dr M. A. Waugh, consultant in charge of the Clinic for Sexually Transmitted $\dot{\omega}$ Diseases at Leeds Infirmary, who sent us the $\vec{\sim}$ specimens.

\section{References}

Gordon, F. B., Dressler, H. R., Quan, A. L., McQuilkin, 월 W. T., and Thomas, J. I. (1972). Effect of ionizing irradiation on susceptibility of McCoy cell cultures to $\vec{\oplus}$ Chlamydia trachomatis. Applied Microbiology, 23, 123129.

Hobson, D., Johnson, F. W. A., Rees, E., and Tait, A. I. (1974). Simplified method for diagnosis of genital and ocular infections with chlamydia. Lancet, $2,555-556$.

Nayyar, K. C., O'Neill, J. J., Hambling, M. H., and Waugh, M. A. (1976). Isolation of Chlamydia trachomatis from women attending a clinic for sexually transmitted diseases. British Journal of Veneral Diseases, 52, 396-398.

Richmond, S. J. (1976). Growth of Chlamydia trachomatis in cell culture. (Letter.) Lancet, 1, 865.

Sompolinsky, D., and Richmond, S. (1974). Growth of Chlamydia trachomatis in McCoy cells treated with Cytochalasin B. Applied Microbiology, 28, 912-914. 